\title{
Technical Efficiency Assessment of Dairy Farm in the South- West Region of Bangladesh
}

\author{
By Fariha Farjana \& Afia Khatun
}

Khulna University

Abstract- The paper concentrates on the measurement of the total factor productivity of dairy farms in the south-west region of Bangladesh. The study used stochastic frontier approach for analyzing the technical efficiency of the dairy farms. Here, seventy dairy farms are considered as a sample. The data reveals that the number of labor and the quantity of food are statistically significant at a 1 percent level of significance. The data also manifests that numerous farm-specific characteristics, i.e. farm size, farmer's age, and amount of credit are statistically significant at 1 percent, 10 percent, and 10 percent respectively. The range of technical efficiency for the farms varies from 26 percent (minimum) to 95 percent (maximum) where the mean value is 68 percent for the dairy farms of the south-west region. This implies that an average output of milk production falls 32 percent short of maximum possible level. Hence, there is scope of improvement in this sector. Therefore, to improve the farm productivity government should provide proper training, and medical treatment facilities for the farms so that the animals become healthy. If it is possible to do so then the farm level production frontier will shift upward.

Keywords: dairy farm, cobb-douglas production function, technical efficiency, south-west region.

GJHSS-E Classification: FOR Code: 149999

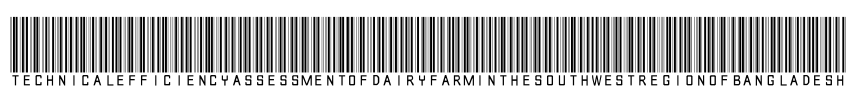

Strictly as per the compliance and regulations of:

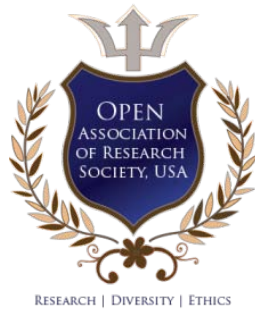

(C) 2020. Fariha Farjana \& Afia Khatun. This is a research/review paper, distributed under the terms of the Creative Commons Attribution-Noncommercial 3.0 Unported License http://creativecommons.org/licenses/by-nc/3.0/), permitting all non-commercial use, distribution, and reproduction in any medium, provided the original work is properly cited. 


\title{
Technical Efficiency Assessment of Dairy Farm in the South-West Region of Bangladesh
}

\author{
Fariha Farjana $^{\alpha} \&$ Afia Khatun $^{\sigma}$
}

\begin{abstract}
The paper concentrates on the measurement of the total factor productivity of dairy farms in the south-west region of Bangladesh. The study used stochastic frontier approach for analyzing the technical efficiency of the dairy farms. Here, seventy dairy farms are considered as a sample. The data reveals that the number of labor and the quantity of food are statistically significant at a 1 percent level of significance. The data also manifests that numerous farm-specific characteristics, i.e. farm size, farmer's age, and amount of credit are statistically significant at 1 percent, 10 percent, and 10 percent respectively. The range of technical efficiency for the farms varies from 26 percent (minimum) to 95 percent (maximum) where the mean value is 68 percent for the dairy farms of the south-west region. This implies that an average output of milk production falls 32 percent short of maximum possible level. Hence, there is scope of improvement in this sector. Therefore, to improve the farm productivity government should provide proper training, and medical treatment facilities for the farms so that the animals become healthy. If it is possible to do so then the farm level production frontier will shift upward.
\end{abstract}

Keywords: dairy farm, cobb-douglas production function, technical efficiency, south-west region.

\section{INTRODUCTION}

1 angladesh is an agricultural country, and its economy is mainly based on agriculture (Saadullah, 2001). Among 140 million people, 80 percent of them lived in the rural area where 80 percent own livestock (Haque, 2007). Agriculture in Bangladesh is characterized by diversified farming like crops, livestock, fisheries, and agro-forestry to meet the household requirements, and minimize the risk and uncertainty (Sharmin et al., 2012). Among different agricultural activities, dairy farming is one of them. The dairy sector is a one of the important contributors to boost the economy (Sharmin et al., 2012). In 2006, the livestock sector directly contributed 3 percent of gross domestic product (GDP). However, indirect benefits like draught power, manure for fuel, and fertilizer are double, i.e. 6 percent of GDP (Haque, 2007).

In Bangladesh, more than 70 percent of the dairy farmers are smallholders and contribute 70-80 percent of the country's total milk production. The growth of milk production increased from 4.1 percent to 7.4 percent in FY 2000-2005 and FY 2005-2008,

Author a: Assistant Professor, Economics Discipline, Khulna University, Khulna, Bangladesh.e-mail: fariha_farjana@yahoo.com

Author $\sigma$ : Graduate, Economics Discipline, Khulna University, Khulna, Bangladesh.e-mail: afiaecon@gmail.com respectively. Even with this faster growth, the per capita milk availability in the year 2008 is only $19 \mathrm{~kg}$, (Hemme et al., 2008) which is far below the requirements (92 $\mathrm{kg} /$ person/year) as notified by the World Health Organization (WHO). The dairy farm is considered as a strong tool to develop a village micro-economy of Bangladesh. It can improve rural livelihoods and alleviate rural poverty (Shamsuddin et al., 2007). To achieve competitiveness, dairy farmers need to find ways of reducing costs and increasing returns (Dayanandan, 2011). Therefore, the objective of the study is to investigate the technical efficiency level of the dairy farms in the south-west region of Bangladesh.

\section{Literature RevieW}

The term efficiency is related to the productivity growth, especially in developing country perspective (Ohajianya, 2005). Efficiency in agriculture is associated with the possibility of farm production to attain the optimum level of output at least cost (Ajibefun, 2000). Ellis (1993) points out three conditions for satisfying the production unit to be efficient under neoclassical assumptions: a) same prices for inputs and outputs, b) same production functions, and c) profit-maximizing behavior. Any violation of at least one point, there is variation in efficiency level. Efficiency is composed of two components, i.e. technical efficiency (TE) and allocative efficiency. The paper concentrates solely on the technical efficiency of the dairy firms in the Southwest region of Bangladesh. Therefore, TE refers to the ability to avoid waste by producing as much output as input usage allows or by using as little input as output production allows (Lovell, 1993).

There are two methods to estimate TE, i.e. Data Envelopment Analysis (DEA) and Stochastic Frontier Analysis (SFA) (Coelli, 2005). Stochastic frontier analysis (SFA) uses econometrics based on the deterministic parameter frontier of Aigner and Chu (1968). SFA method can handle cross-section data and panel data. However, DEA deals with panel data. Sharafat (2013), Kompas and Che (2004), Masunda and Chiwesh (2015), Binici et al. (2006), Zhu et al. (2012) and others use SFA technique for studying technical efficiency of dairy farms in different countries of the world where they find mean TE is 39.5 percent, 87.39 percent, 54.9 percent, 50 percent, 61.4 percent, 55.3 percent, and 78.8 percent respectively. Since the data used in the 
paper is cross-section data, the researchers used the SFA approach.

Seyoum et al. (1998), Asogwa, et al. (2011), Umeh and Asogwa (2011), and Oladeebo (2012) apply the Cobb-Douglas stochastic frontier model for efficiency analysis. For the simplicity of analysis, this study considers the Cobb-Douglas stochastic frontier model. Smallholder milk producers played pivotal role in the dairy market of Bangladesh. They sold milk directly to consumers or milk broker at local markets. They supplied all domestic milk for the informal and traditional markets (Quddus, 2013). Khan et al. (2013) find that average milk production per cow is 6.05 liter per day. Quddus (2013) finds that 35 percent of farmers owned milk yield 11.5 liter milk per day. Hussain (2013) examines that in Bangladesh, almost two out of every three household rear cattle to produce milk for personal consumption.

\section{a) Variables identification for Empirical Model}

Farm size has a positive relationship with dairy farm efficiency. Sarafat (2013) and Tauer (2001) find a positive association between farm size and productivity at 1 percent and 5 percent significant level. These results are the same for other authors' findings like Kalirajan and Flinn (1983), Kalirajan and Shand (1985), and Belbase and Grabowski (1985).

A common approach to measure literacy rate is years of schooling. Belbase and Grabowski (1985), Kalirajan and Shand (1985) find a positive correlation between TE and education. However, Kalirajan and Shand (1985) report that there is no significant relationship between these two variables. Experience is the number of years that farmers are involved in farming activities. This coefficient of experience was positive, and it was statistically significant at the 1 percent level in the TE model of Khai and Yabe (2011); Asogwa et al. (2011). Farming experience positively contributed to improve technical efficiency (Masunda and Chiweshe, 2015).

The term area is the size of the land cultivated for farming. Khai and Yabe (2011) detected that an increase in area increases TE. It is statistically significant at 1 percent level. On the other hand, Asogwa et al. (2011) find that area has a negative impact on TE. Gelan et al. (2010) detected that Off-farm income has a negative but insignificant effect on TE. Contact with an extension officer during the past year is positively related to efficiency but statistically insignificant. The relationship between TE and the contact with extension services is negative (Sarafat, 2013). Asogwa et al. (2011) cite that household size positively affects the TE.

\section{ili. Methodology}

\section{a) Study Area and Sampling}

This study considers the South-west region of Bangladesh as the study area. The authors select two districts for this study. The main occupation of the people of these two areas is agriculture. About 39.43 percent of the total population of Khulna district and 39.84 percent of the total population of Jessore district are involved with agricultural activities. People who have milk-producing cows, these farms are selected as samples. People who have at least three cattle are treated as a farm (Abdulai, 1998). This study also considers those dairy farms which have at least 3 cows. Here the number of farm animals means the total size of milking cows, calves and oxen. The total sample size is 70 , where each of the districts cover 35 dairy farms. Authors apply Purposive sampling technique to select the sample from the population. The sample unit of this study is those farmers who have their own dairy farm in the study area. Table 1 delineates the detail of the sampling unit distribution.

Table No. 1: Distribution of Location and Sample Size

\begin{tabular}{ccc}
\hline Name of District & Name of Upazila & Sample Size \\
\hline Khulna & Khalishpur & 5 \\
& Dumuria & 15 \\
Jessore & Sahapur & 15 \\
& Barakpur & 10 \\
& Bodh Khana & 10 \\
& Chondipur & 15 \\
& Total & 70 \\
\hline & & Source: Authors' Compilation
\end{tabular}

\section{b) Analytical Tools}

The efficiency level of a farm is measured by the ratio of actual output to the maximum attainable output. The technical efficiency shows the farm's ability to maximize output with a set of given input. The value of TE ranges from 0 to 1 . Here, TE $=1$ indicates that the farm is producing on its production frontier and is said to be technically efficient. Hence, (1-TE) represents the gap between actual production and optimum attainable production that is possible to achieve by moving the firm towards the frontier through readjusting inputs (Ahmed et al., 2010). If the farms utilize all the factors properly and efficiently, then the production would be at a maximum level. However, if the farms are not capable of using the factors of production efficiently then there will be a gap between the maximum level of production and 
the actual level of production, and this gap will represent inefficiency. Therefore, in this paper with the help of Stochastic Frontier Analysis (SFA) authors analyzed the factors that influence the dairy farms' production and farm-specific efficiency.

c) Estimation of Cobb-Douglas Stochastic Production Function

The proponent of Cobb-Douglas production function is Charles Cobb and Paul Douglas who developed the concept of production function estimation in 1928. Many studies used the Cobb-Douglas function to access the farm level production, particularly in those relating to developing agriculture. Therefore, this study employed the following Cobb-Douglas Stochastic functional form. Hence, the model is

$$
\ln Y_{i}=\beta_{0}+\sum_{i=1}^{n} \beta_{i} \ln X_{i}+V_{i}-U_{i}
$$

Where $Y_{i}$ denotes the output, i.e. liters of milk production per month, $X_{i}$ indicates the vector of explanatory variables. Table 2 demonstrates the description of the variables which authors used for further analysis. Here, $\beta_{0}$ is an intercept term; $\beta_{i}$ is coefficient of $i^{\text {th }}$ independent variables, $V_{i}$ is statistical disturbance term (random error term), $U_{i}$ is technical efficiency effect independent of $V_{i}$, i is the $i^{\text {th }}$ dairy farmer, where $i=1, \ldots \ldots, n$.

Table No. 2: List of Variables for Cobb-Douglas Production Function Estimation

\begin{tabular}{ccccc}
\hline Sl. No. & Variable & Unit of Measurement & Expected Sign & Literature \\
\hline 1 & Milk Production & $\begin{array}{c}\text { Dependent Variable } \\
\text { Liter / Month } \\
\text { Independent Variable }\end{array}$ & NA & Sharafat, 2012 \\
1 & Labor & Number / Month & - & Binci et al., 2006 \\
2 & Quantity of Feed & Kg / Month & + & Sharafat, 2012 \\
3 & Medicinal Cost & BDT / Month & + & Sharafat, 2012 \\
4 & Electricity Cost & BDT / Month & + & Salma, 2014 \\
\hline & & & & Source: Authors' Compilation
\end{tabular}

\section{d) Factors of Technical Efficiency Assessment}

In this segment with the help of equation 2 authors tried to find out the factors that affect farmspecific TE. The equation is as follows:

$$
\mathrm{TE}_{\mathrm{i}}=\delta_{0}+\delta_{i} \sum_{i=1}^{n} Z_{\mathrm{i}}+\mathrm{e}_{\mathrm{i}}
$$

Where $T E_{i}$ reveals efficiency function/total factor productivity, $Z_{i}$ is the vector of explanatory variables, $\delta_{0}$ the is intercept term, $\delta_{i}$ is the parameter for $i^{\text {th }}$ independent variables and $e_{i}$ is the error term. Table 3 represents a brief explanation of the vector of explanatory variable $Z_{i}$ with the literature support. The values of unknown coefficients in equation (1) and (2), that is, $\beta$ and the $\delta$ can be obtained jointly by using the maximum likelihood method (ML). Using equation 3 authors estimated the value of technical efficiency for each of the dairy farms.

$$
\mathrm{TE}_{\mathrm{i}}=\exp \left(-\mathrm{U}_{\mathrm{i}}\right)
$$

\begin{tabular}{|c|c|c|c|c|}
\hline SI. No. & Variable & Unit of Measurement & Expected Sign & Literature \\
\hline \multicolumn{5}{|c|}{ Dependent Variable } \\
\hline 1 & Milk Production & Liter / Month & $\mathrm{NA}$ & Sharafat, 2012 \\
\hline \multicolumn{5}{|c|}{ Independent Variable } \\
\hline 1 & Farm Size & No. of Cattle & + & Sharafat, 2012 \\
\hline 2 & Age of Respondents & Year & + & Masunda \& Chiweshe, 2015 \\
\hline 3 & Educational Status & Year of Schooling & + & Binci el at., 2006. \\
\hline 4 & Farming Experience & Farming Age (Year) & + & Sharafat, 2012 \\
\hline 5 & Household Size & No. of Family Member & + & Todsadee et. al., 2012 \\
\hline 6 & Off-Farm Income & BDT / Month & + & Jwanya \&Gojing, 2014 \\
\hline 7 & Amount of Credit & BDT / Month & $?$ & Authors' Compilation \\
\hline 8 & Training Facility & Dummy ( $1=$ Yes, 0 =No) & + & Salma, 2014 \\
\hline 9 & $\begin{array}{c}\text { Contact with Extension } \\
\text { Officer }\end{array}$ & $\begin{array}{l}\text { Dummy }(1=\text { Contact with } \\
\text { Extension Officer, } 0=\text { Otherwise) }\end{array}$ & + & Binci el at., 2006 \\
\hline
\end{tabular}

Table No. 3: List of Variables for Technical Inefficiency Assessment 


\section{Summary Statistics}

Milk production depends on various factors like farm size, feed, labor, training, credit facility, socioeconomic factors, and others. Table 4 presents the descriptive statistics of the variables used in the stochastic frontier production function estimation. The mean value of milk production is 2836.5 liter per month. The mean farm size is 11 cattle with a minimum farm size of 4 cattle and maximum of 37 cattle. For milk production, the average number of labor is four, where both family and hired labors are included. The average quantity of feed is $10035 \mathrm{~kg}$. The medicinal cost comprises the vitamin cost, veterinary cost, breeding cost etc., and monthly BDT3471 is spend on cows. The farms expend minimum BDT 400 and maximum BDT3000 for electricity purpose. Meanwhile, the average amount incurred for electricity is BDT 700.

Table No. 4: Descriptive Statistics of the Study Variables for Milk Production

\begin{tabular}{cccccc}
\hline Variables & Unit of Measurement & Mean & Std. Dev. & Min. & Max. \\
\hline Milk Production & Kg & 2836.5 & 1761.88 & 270 & 9160 \\
Farm Size & Number & 11.44 & 6.84 & 4 & 37 \\
Labor & Number & 3.5 & 1.98 & 1 & 10 \\
Quantity of Feed & Kg & 10035.26 & 5456.22 & 500 & 26695 \\
Medicinal Cost & BDT & 3471.42 & 2344.02 & 400 & 15000 \\
Electricity Cost & BDT & 705.85 & 611.81 & 200 & 3000 \\
Age & Year & 43.24 & 9.08 & 20 & 65 \\
Education & Year & 6.42 & 3.67 & 0 & 17 \\
Household Size & Number & 5.14 & 1.82 & 3 & 14 \\
Off-farm Income & BDT & 19392.86 & 15966.65 & 0 & 60000 \\
Farming Experience & Year & 21.57 & 6.23 & 8 & 35 \\
Amount of Credit & BDT & 139500 & 183836.2 & 0 & 800000 \\
Training Facility & Dummy $(1=$ Yes, $0=$ No) & 1.4 & 0.49 & 0 & 1 \\
Contact with Officer & Dummy (1=Yes, $0=$ No) & 1.02 & 0.16 & 0 & 1 \\
\hline
\end{tabular}

N.B.: $N=$ Number of Observation; Std. Dev. = Standard Deviation

Min = Minimum; Max = Maximum.

Source: Authors' Compilation

In Table 4, the average farmer age in the sample is 43 years old. The average year of schooling is six years, and farming experience is 22 years. These data show that most of the producers are middle aged group and experienced. However, they are not well educated, and not hiring enough labor for their farm. The average household size is 5 in number, and the maximum amount of taking a loan is BDT 800000 . The average income derived from off-farm activity is BDT 19000. The loan burden indicates that the income of the farmers is not sufficient to meet up their daily needs. Therefore, farmers are taking a higher amount of loans. The average training facility, and contact with the officer are 1.4 and 1.03 percent, respectively.

\section{a) Explanation of the Estimates of the Cobb-Douglas} Stochastic Frontier Model

Table 5 delineates the parameter estimates of the Cobb-Douglas stochastic frontier model. The estimated output elasticity considering labor, the quantity of feed, medicinal cost, and electricity cost are $0.26,0.48,0.21$, and -0.03 , respectively. These coefficients represent the percentage change in the dependent variable as a result of the percentage change in the independent variables. In the regression analysis the explanatory variables are not multicollinear. Since the mean value of VIF is 1.92 which is less than 4 , bears the testimony that the data are not multicollinear.
The coefficient of labor is 0.26 . It indicates that a 1 percent increase in the number of farm-worker, milk production also increased by 0.26 percent when all other variables are constant. It is statistically significant at 1 percent level. Meanwhile, in Table 5 the coefficient of the quantity of feed is 0.48 which describes that a 1 percent increases in feed quantity, milk production also increased by 0.48 percent holding other things constant. The coefficient of medicinal cost is 0.21 , which implies a positive relationship between milk production and medicinal cost. A 1 percent increases in medicinal cost increases milk production by 0.21 percent. It is statistically significant at 5 percent significant level. Variances of one-sided error term $\ln \sigma^{2} u$ (variance of inefficiency term) and variances of two-sided error term $\ln \sigma^{2} v$ (variance of stochastic disturbance term) are also statistically significant at 1 percent level. The parameter Lambda $(\lambda)$ is greater than one. According to Tadesse and Krishnamoorthy (1997) the value of $\lambda$ more than 1 indicates a good fit for the model. 
Table No. 5: Estimates Cobb-Douglas Production Function

\begin{tabular}{cccc}
\hline Variables & Coefficient & Standard Err. & t-value \\
\hline In labor & $0.26^{\star \star \star}$ & 0.10 & 2.65 \\
In Quantity of Feed & $0.48^{\star \star \star}$ & 0.07 & 6.27 \\
In Medicinal Cost & $0.21^{\star \star}$ & 0.10 & 2.00 \\
In Electricity Cost & -0.03 & 0.06 & -0.50 \\
Constant & 1.97 & 0.87 & 2.25 \\
\hline $\ln \sigma^{2} v$ & $-3.69^{\star \star \star}$ & 0.89 & -4.11 \\
In $\sigma^{2} \mathrm{u}$ & $-1.23^{\star \star \star}$ & 0.36 & -3.34 \\
Sigma & 0.31 & 0.09 & 0.16 \\
Lambda & 3.42 & & \\
Likelihood Ratio & 2.07 & & \\
\hline
\end{tabular}

N.B.: ** and ${ }^{* * *}$ denote $5 \%$ and $1 \%$ significance level respectively.

Source: Authors' Compilation

b) Determinants of Technical Efficiency

Table 6 represents the estimated coefficient for the TE model and suggests several factors to explain total factor productivity. Table 6 shows that if farm size increase by 1 number of cattle, it will lead to an increase in technical efficiency of almost 0.009, and it is significant at a 1 percent level of significance. This increase in TE due to farm size increase is attributable to the economies of scale, which implies as the farm size increases, the per unit production cost reduces. An increase of farm age by one year a decrease in the TE at
0.004 , and it is statistically significant at a 10 percent significance level. That is with the increase of farm age by one year, total factor productivity of the farm is decreasing. If the number of credit increases by BDT 1 , TE increased by 0.00002 , and it is statistically significant at a 10 percent level of significance. The other factors, i.e. off-farm income, education, household size, farming experience, training facility, and contact with the officer are not statistically significant. The value $R^{2}$ is 0.31 , implying that the explanatory variables can explain 31 percent variation in the dependent variable.

Table No. 6: Technical Efficiency Parameters in Stochastic Frontier Function

\begin{tabular}{cccc}
\hline Variables & Coefficient & Standard Error & t-value \\
\hline Farm Size & $0.009^{* * *}$ & 0.003 & 3.02 \\
Farm Age & $-0.004^{*}$ & 0.002 & -1.83 \\
Education & 0.002 & 0.005 & 0.41 \\
Household Size & -0.01 & 0.013 & -0.75 \\
Off-farm Income & 0.000001 & 0.000001 & 1.36 \\
Farming Experience & -0.0007 & 0.003 & -0.22 \\
Amount of Credit & $0.00002^{*}$ & 0.0000001 & 1.89 \\
Training Facility & -0.04 & 0.04 & -1.20 \\
Contact with officer & -0.13 & 0.11 & -1.11 \\
Constant & 0.98 & 0.18 & 5.30 \\
$N$ & 70 & & \\
$R^{2}$ & 0.30 & & \\
\hline
\end{tabular}

N.B.: * and ${ }^{* * *}$ denote $10 \%$ and $1 \%$ significance level respectively, $N=$ Number of Observation

Source: Authors' Compilation

c) Farm Level Technical Efficiency

Table 7 illustrates the farm level technical efficiency of the dairy farm. The table reveals a wide variation in the level of TE among the farmers. It ranges from 0.00 to 1.00 . In this paper, the range of technical efficiency for the dairy firms is from 0.26 (minimum) to 0.95 (maximum). The mean TE score is 0.68; this indicates that an average milk production falls 32 percent short of the maximum possible level. Therefore, with the available set of inputs it is possible to increase the output of dairy farm by average 32 percent in the short run. 
Table No. 7: Distribution of Technical Efficiency

\begin{tabular}{ccc}
\hline Technical Efficiency & Frequency & Percentage \\
\hline $0.00-0.10$ & 0 & 0 \\
$0.11-0.20$ & 0 & 0 \\
$0.21-0.30$ & 3 & 4 \\
$0.31-0.40$ & 2 & 3 \\
\hline $0.41-0.50$ & 7 & 10 \\
$0.51-0.60$ & 11 & 16 \\
$0.61-0.70$ & 9 & 13 \\
$0.71-0.80$ & $1 \overline{2}$ & 24 \\
$0.81-0.90$ & $1 \varepsilon$ & 26 \\
$0.91-1.00$ & 3 & 4 \\
\hline Total & $7 C$ & 100 \\
\hline Descriptive Statistics & Mean: 0.68 & \\
& Minimum: 0.26 & \\
\hline
\end{tabular}

Source: Authors' Compilation

Table 7 shows that the majority of the dairy farms belong to the most efficient category, i.e. 50 percent farms have total factor productivity score ranging from 0.71 to 1.00 . However, few are less efficient, which is 17 percent milk production units are at the range of 0.01 to 0.50 total factor productivity score. Although, on average, the technical efficiency of milk production of a dairy farm is satisfactory but none of the dairy farms had TE score 1.00. The TE scores of different dairy farms of the study revel that to improve the firm-level productivity there is huge scope of improvement.

\section{Conclusion}

Bangladesh is an agro-based country, and most of the rural people are engaged in different agricultural activities. They are involved in this sector as their hereditary business. The analysis of the study area author finds that the average cost of milk production of 70 dairy farms is BDT 93886, and the average revenue of milk production is BDT 95832. The profit figure for this sector is small. It is because of the low milk prices, and high feed prices of cattle. But as a hereditary business, most of the respondents cannot leave it. Some respondents claim that as a low milk price, they want to convert their business from milk-producing cows to beef-producing cows. Because they think that meatproducing cattle business is more profitable than milkproducing cattle business. As a low milk price, profit in this sector is decreasing.

A dominant portion of farms mobilize revenue from milk selling, where a large portion of the cost is spending on feeding. In the production function, three variables are statistically significant. The number of labor and the quantity of feed are significant at a 1 percent level, and the medicinal cost is significant at a 5 percent level of significance. In the case of farm-level efficiency analysis three variables are statistically significant among the seven explanatory variables. Age and amount of credit are significant at the 10 percent level, and farm size is statistically significant at 1 percent level. The mean technical efficiency of a dairy farm is 68 percent, which revealed a wide variation of technical efficiency among the farmers, and it is possible to increase the output of the dairy farms.

If people are educated, they can efficiently use inputs and produce more output. So education is a must for all and people have to engage in the different training programs so that they can train themselves correctly. The government should give different facilities in the dairy sector and ensure the availability of medicine and treatment facilities. Therefore, from the above discussion, it can be concluded that dairy farming is a very important and essential sector for Bangladesh. It helps to boost the economy of a country, increases employment opportunity, and reduces the unemployment problem.

\section{References Références Referencias}

1. Ahmed, T., Hashem, M.A., Khan, M. and Hossain, M.M. (2010). Factors Related to Small Scale Cattle Fattening in Rural Ares of Bangladesh, Bangladesh Journal of Animal Science, 2010, 39 (1 \& 2), pp. 116-124.

2. Aigner, D.J. and Chu, (1968). Estimating the Industry Production Function, American Economic Review, 84(4), 826-839. 
3. Ajibefun, I.A. (2000). Use of Econometric Models in Technical Efficiency Analysis as Application to the Nigerian Small Scale Farmers, Nigerian Statistical Association Program, 15, pp. 26-39.

4. Asogwa, B., Ihemeje, J. and Ezihe, J. (2011). Technical and Allocative Efficiency Analysis of Nigerian Rural Farmers: Implication for Poverty Reduction, Agricultural Journal, 6 (5), 243-251.

5. Belbase, K. and Grabowski, R. (1985). Technical Efficiency in Nepalese Agriculture. The Journal of Developing Areas, 19 (4), pp. 515-525.

6. Binici, T., Demircan, V. and Zulauf, C.R. (2006). Assessing Production Efficiency of Dairy Farms in Burdur Province, Turkey, Journal of Agriculture and Rural Development in the Tropics and Subtropics, 107(1), pp. 1-10.

7. Coelli, T., Rahman, S. and Thirtle, C. (2002). Technical, Allocative, Cost and Scale Efficiencies in Bangladesh Rice Cultivation: A Non-parametric Approach, Journal of Agricultural Economics, 53(3), pp. 607-626.

8. Coelli, T.J., Rao, C.J., Donnell, O. and Battese, G.E. (2005). An Introduction to Efficiency and Productivity Analysis. New York, USA, pp. 349.

9. Dayanandan, R. (2011). Production and Marketing Efficiency of Dairy Farms in Highland of Ethiopia An Economic Analysis, International Journal of Enterprise Computing and Business Systems, Vol. 1.

10. Ellis, F. (1993) Peasant Economics, Cambridge University Press.

11. Gelan, Ayele, Muriithi and Beatrice, (2010). Measuring and Explaining Technical Efficiency of Dairy Farms: A Case Study of Smallholder Farms in East Africa, Agricultural Economics Review, 16, pp. 45-58.

12. Haque, S.A.M.A. (2007). Bangladesh: Social Gains from Dairy Development, Smallholder Dairy Development: Lessons Learned in Asia, pp. 8-21.

13. Hemme, T. Ndambi, O. A., Garcia, O., Balikowa, D., Kiconco, D., and Latacz, L. U. (2008). Milk Production Systems in Central Uganda: A Farm Economic Analysis. Tropical Animal Health and Production, 40, pp. 269-279.

14. Hussain, S. (2013). The Bangladesh Dairy Market, Global Agricultural Information Report, USDA foreign Agricultural Service, New Delhi.

15. Kalirajan, K.P. and Flinn, J.C. (1983). The Measurement of Farm Specific Technical Efficiency, Pakistan Journal of Applied Economics, Vol. 2, pp. 167-80.

16. Kalirajan, K.P. and Shand, R.T. (1985). Economics in Disequilibrium: An Approach from the Frontier, Macmillan India Ltd., New Delhi.

17. Khai, H.V. and Yabe, M. (2011). Productive Efficiency of Soybean Production in the Mekong River Delta of Vietnam, Kyushu University, Japan.
18. Kompas, T. and Che, T.N. (2004). Technology Choice and Efficiency on Australian Dairy Farms, The Australian Journal of Agricultural and Resource Economics, 50, pp. 65-83.

19. Lovell, C.A.K. (1993). Production Frontiers and Productive Efficiency, The Measurement of Productive Efficiency, Oxford University Press.

20. Masunda, S. and Chiweshe, A.R. (2015). A Stochastic Frontier Analysis on Farm Level Technical Efficiency in Zimbabwe: A Case of Marirangwe Smallholder Dairy Farmers, Journal of Development and Agricultural Economics, 4, pp. 34-67.

21. Ohajianya D.O. (2005). Economics Efficiency among Small Scale Poultry in Imo State; Stochastic Frontier Production Model Approach, International Journal of Agriculture and Rural Developmentl, 6, pp.18-25.

22. Oladeebo, J.O. (2012). Technical Efficiency and Rural Poverty among Farmers in Nigeria: A Gender Perspective, Global Journal of Science Frontier Research, 12(8-D).

23. Quddus, M. (2013). Adoption of Dairy Faring Technologies by Small Farm Holders: Practices and Constraints, Bangladesh Journal of Animal Science, 41(2), pp. 124-135.

24. Saadullah, M. (2001). Smallholder Dairy Production and Marketing Opportunities and Constraints in Bangladesh; Proceedings of A South-South Workshop Held at National Dairy Development Board, Anand, India.

25. Seyoum, E.T., Battese, G.E., and Fleming, E.M. (1998). Technical Efficiency and Productivity of Maize Producers in Eastern Ethiopia: A Study of Farmers within and outside the Sasakawa Global 2000 Project, Agricultural economics, 19(3), pp. 341-348.

26. Shamsuddin, M., Alam, M. M., Hossein, M. S., Goodger, W. J., Bari, F. Y., Ahmed, T. U., Hossain, M. M. and Khan, A.H.M.S.I., (2007). Participatory Rural Appraisal to Identify Needs and Prospects of Market-oriented Dairy Industries in Bangladesh, Tropical Animal Health and Production, 39, pp. 567-581.

27. Sharafat, A.A. (2013). Technical Efficiency of Dairy Farms: A Stochastic Frontier Application on Dairy Farms in Jordan, Journal of Agricultural Science, 5(3), pp. 26-31.

28. Sharmin, S., Islam, S. and Hasan, K. (2012). Socioeconomic Analysis of Alternative Farming Systems in Improving Livelihood Security of Small Farmers in Selected Areas of Bangladesh, The Agriculturists, 10 (1), pp. 51-63.

29. Tauer L. (2001). Efficiency and Competitiveness of the Small New York Dairy Farm. Journal of Dairy Science, 84, pp. 2573-2576. 
30. Umeh, J.C. and Asogwa, B.C. (2011). Econometric Model of Poverty for the Farming Households in Nigeria: A Simultaneous Equation Approach, 2nd International Conference on Agricultural and Animal Science (CAAS 2011), Maldives, pp. 25-26.

31. Zhu, X., Demeter, R.M. and Lansink, A.O. (2012). Technical Efficiency and Productivity Differentials of Dairy Farms in Three EU Countries: The Role of CAP Subsidies, Agricultural Economics Review, 13, pp. 1-66. 